\title{
PREDHODNO POROČILO O RAZISKOVANJU MINIMALNIH TEMPERATUR V MRAZIŠČIH POZIMI 2004/2005
}

\author{
Darko Ogrin*, Matej Ogrin** \\ Oddelek za geografijo, Filozofska fakulteta v Ljubljani, Aškerčeva 2, I000 Ljubljana \\ *e-mail: darko.ogrin@ff.uni-lj.si \\ * e-mail: matej.ogrin@siol.net
}

Kratki znanstveni prispevek

COBISS 1.03

\begin{abstract}
Izvleček
Temperaturne razmere v mraziščih se precej razlikujejo od razmer, ki smo jih vajeni drugje po Sloveniji. Mehanizmi ohlajanja so bolj intenzivni, reliefna oblika pa omogoča nemoteno nočno ohlajanje, kar privede $\mathrm{v}$ radiacijskem tipu vremena do velikih razlik glede na okolico. Poskusne terenske meritve v zimi 2004/2005 potrjujejo znana fizikalna dejstva in kažejo, da se v teh mraziščih ob ugodnih meteoroloških pogojih pojavljajo precej nižje temperature od absolutnih minimumov izmerjenih v mreži ARSO.
\end{abstract}

Ključne besede: minimalna temperatura, nočno ohlajanje, jezero hladnega zraka, konkavne reliefne oblike, temperaturna inverzija, mrazišča.

\section{PRELIMINARY REPORT ABOUT MEASURING EXTREME NOCTURNAL TEMPERATURES IN CONCAVE RELIEF SHAPES IN WINTER 2004/2005}

\begin{abstract}
Temperature conditions in concave relief shapes differ very much from the conditions that are known as typical for Slovenia. Processes of nocturnal cooling in radiative type of weather are more intensive, relief shape enables undisturbed and strong cooling until morning, which results in big temperature differences in relation to area outside the relief shape. Experimental results made in winter 2004/2005, confirmed that when right meteorological conditions are fulfilled, temperatures in such relief shapes are much lower than in areas where absolute minimums measured within the national observing service net.
\end{abstract}

Key words: minimum temperature, nocturnal cooling, cold air pool, concave relief shape, temperature inversions. 


\section{UVOD}

Konkavne reliefne oblike v radiacijskem, anticiklonalnem tipu vremena postanejo območja jezer hladnega zraka. Če so te reliefne oblike oblikovane tako, da je odtekanje zraka onemogočeno, potem se ujeti, ohlajeni zrak v njih nemoteno ohlaja do jutra. Te reliefne oblike, ki so lahko različne velikosti in najrazličnejših oblik, so znane kot mrazišča. Mnoga od njih so znana le lokalno, za mnoge verjetno niti ne vemo, na nekatera pa nas spomnijo že njihova imena, kot npr. Mrzli dol, Mrzla dolina, Ledenica ipd.

Klimatske razmere v mraziščih so ekstremne. Že samo ime nam pove, da gre za območja z nižjimi temperaturami, pri čemer pa obstajajo razlike med mrazišči. Nekatera imajo trajen temperaturni obrat, $v$ drugih se pojavi redkeje. $V$ mraziščih so spremenjeni tudi drugi klimatski pogoji, kot so osončenost, prevetrenost, zračna vlaga, trajanje snežne odeje ipd. Vse to oblikuje mrazišča tudi kot posebna območja z značilnim rastjem. V dovolj globokih in izrazitih mraziščih se pojavi tudi vegetacijski obrat, kjer se v posameznem pasu mrazišča oblikuje naravnim pogojem ustrezno rastje.

Razmeram v mraziščih so slovenski raziskovalci namenili kar nekaj raziskav. Med geografi je to problematiko verjetno najpogosteje intenzivno preučeval Gams (Gams, 1972, 1974), (Gams in sod. 1979), (Petkovšek in sod. 1969)

$\mathrm{V}$ njegovih raziskavah so podani osnovni naravno geografski pogoji in temperaturne razmere $v$ njih. $Z$ razmerami v mraziščih so se veliko ukvarjali tudi meteorologi, ki so prišli do nekaterih ključnih spoznanj pri procesih nočnega ohlajanja zraka v mraziščih, kar je pojasnilo nekatera dejstva, ki so bistvena pri poznavanju teh procesov. (Petkovšek in sod 1970)

Mrazišča so opisali tudi tuji avtorji (Barany, 1967, Wagner 1970). Zanimivo je, da kljub podatkom o izredno nizkih temperaturah v Avstriji, slovenski raziskovalci o podobnih rezultatih iz mrazišč v Sloveniji ne poročajo. Razlog temu je dejstvo, da so bile raziskave opravljene $\mathrm{v}$ času, ko se ekstremno nizke temperature zaradi danih pogojev niso mogle pojaviti. V splošnem pogoji v mraziščih na slovenskem ozemlju niso bistveno drugačni od tistih v alpskih državah in na Madžarskem.

\section{POGOJI NOČNEGA OHLAJANJA}

Temperaturne razmere ponoči v mraziščih pogojuje več dejavnikov. Kadar prevladuje advektivni (vetrovni) tip vremena ali kadar oblačnost preprečuje radiacijsko ohlajanje tal, se temperatura mrazišč bistveno ne razlikuje od temperature okolice. $V$ t.i. radiacijskem tipu vremena, ko na temperaturo vpliva le razmerje med prejetim sevanjem Sonca in oddanim sevanjem tal, pa so nočne in jutranje temperaturne $v$ mrazišči bistveno drugačne.

Že v poznih popoldanskih urah, takoj ko Sonce ne doseže dna mrazišč, se v njih prične nabirati hladen zrak. Ta z osenčenih pobočij počasi polzi proti dnu. V kolikor je mrazišče zaprto, hladen zrak v njem tudi ostane (kraška polja, vrtače, udornice..), sicer (alpske doline) 
odteka navzdol. Zrak, ki obmiruje na dnu mrazišča se radiacijsko ohlaja naprej. Radiacijsko ohlajanje zraka na dnu mrazišč omogoči, da je pri tleh najhladnejši in najtežji zrak. To je za temperaturo na dnu mrazišč zelo pomembno, saj je zrak, ki priteka proti dnu v poznejših urah manj mrzel in zato lažji. Zaradi tega se ustavlja nad ohlajenim zrakom in tako se mrazišče polni, plast za plastjo. To pomeni, da na dnu mrazišč ohlajanje poteka nemoteno od poznega popoldneva do naslednjega jutra.

Ohlajanje zraka v mraziščih je odvisno od večih dejavnikov.

a) Oblika mrazišč: bolj kot je mrazišče odprto, hitreje se lahko ohlaja. Ker je poglavitni člen, ki vpliva na temperaturo dolgovalovno sevanje tal, je zelo pomembno, da površina tal v mrazišču nemoteno seva toploto $\mathrm{v}$ vesolje. V strmih in zaprtih mraziščih se sevanje odbija od pobočij in se vrača kot proti sevanje, poleg tega pa proti tlom sevajo tudi pobočja. Zato se močneje ohladijo plitva mrazišča od globljih. Vendar so režimi ohlajanja v plitvih mraziščih pogosto moteni zaradi vetra nad njimi, saj veter prinaša toplejši zrak v mrazišča in odnaša ohlajenega iz njih. Zato je za plitva mrazišča zelo pomembno, da je brezvetrje tudi nad mrazišči in ne samo $\mathrm{v}$ mraziščih.

b) Nadmorska višina: višje kot ležijo mrazišča, hladnejša so. Radiacijsko ohlajanje močno ovira vlaga v zraku, saj je vodna para eden najučinkovitejših toplogrednih plinov in zadržuje sevanje tal ter seva nazaj. Višje kot leži mrazišče, manj je nad njim atmosfere in s tem vodne pare (ki je vedno prisotna atmosferi), ki bi onemogočala izrazito nočno ohlajanje.

c) Podlaga: Za učinkovito nočno ohlajanje mora podlaga zadostiti pogoju, da prepreči pretok toplote iz globljih plasti tal na površino, da se površina lahko nemoteno ohlaja. Gozd zadržuje izrazito močno ohlajanje tal (v gozdu je tudi manj rose). Skalnata podlaga onemogoča močno ohlajanje zaradi intenzivnega prevajanja toplote iz globljih plasti kamnine na površje. Pri kopni podlagi je za močno ohlajanje idealna suha, poležana trava, saj se med tlemi in poležano travo ustvari zračna plast, ki učinkovito preprečuje dotok toplote iz tal na površino. Podlaga, ki omogoča najintenzivnejše ohlajanje, je snežna odeja, ki je odličen izolator in hkrati odličen sevalec dolgovalovnega sevanja. $\mathrm{S}$ tem je onemogočen prenos toplote iz tal na površje, snežna odeja pa se intenzivno ohlaja in s tem tudi zrak nad njo. Med različnimi vrstami snega je za ohlajanje najprimernejši nov in suh sneg, zato so za ekstremne temperaturne minimume najprimernejše prve noči po sneženju.

d) Meteorološki pogoji: Jasne in mirne noči. Za močno nočno ohlajanje je poglavitno mirno in jasno ozračje ter suh zrak, oziroma nizka temperatura rosišča. V poznih zimskih mesecih so zračne mase ob prodorih mrzlega zraka hladnejše in bolj suhe (zato je ob takih prodorih po nižinah februarja manj megle kot decembra), zato so pogoji za izrazit mraz tedaj ugodnejši.

e) Dolžina noči: je tudi pomembna, vendar ni odločilna, kar pomeni, da se ekstremno nizke temperature lahko pojavijo tudi v obdobjih, ko noči niso najdaljše. Bolj pomembni so nizka vlaga, jasno nebo in brezvetrje, saj lahko temperatura skokovito pade $\mathrm{v}$ nekaj urah, potem pa do jutra le še malo ali celo nič. 
Slika 1: Bloško polje. Močno radiacijsko ohlajanje in nabiranje zraka v kraških poljih povzroči izrazito talno inverzijo, ki zadržuje dim individualnih kurišč nekaj metrov nad slemeni streh. (Fotografija: M. Ogrin)

Picture 1: Bloke field. Intensive radiative cooling and forming of cold air pool in karst fields forms a strong low temperature inversion, which holds the smoke from houses within the inversion few meters above the houses. (Photo: M. Ogrin)

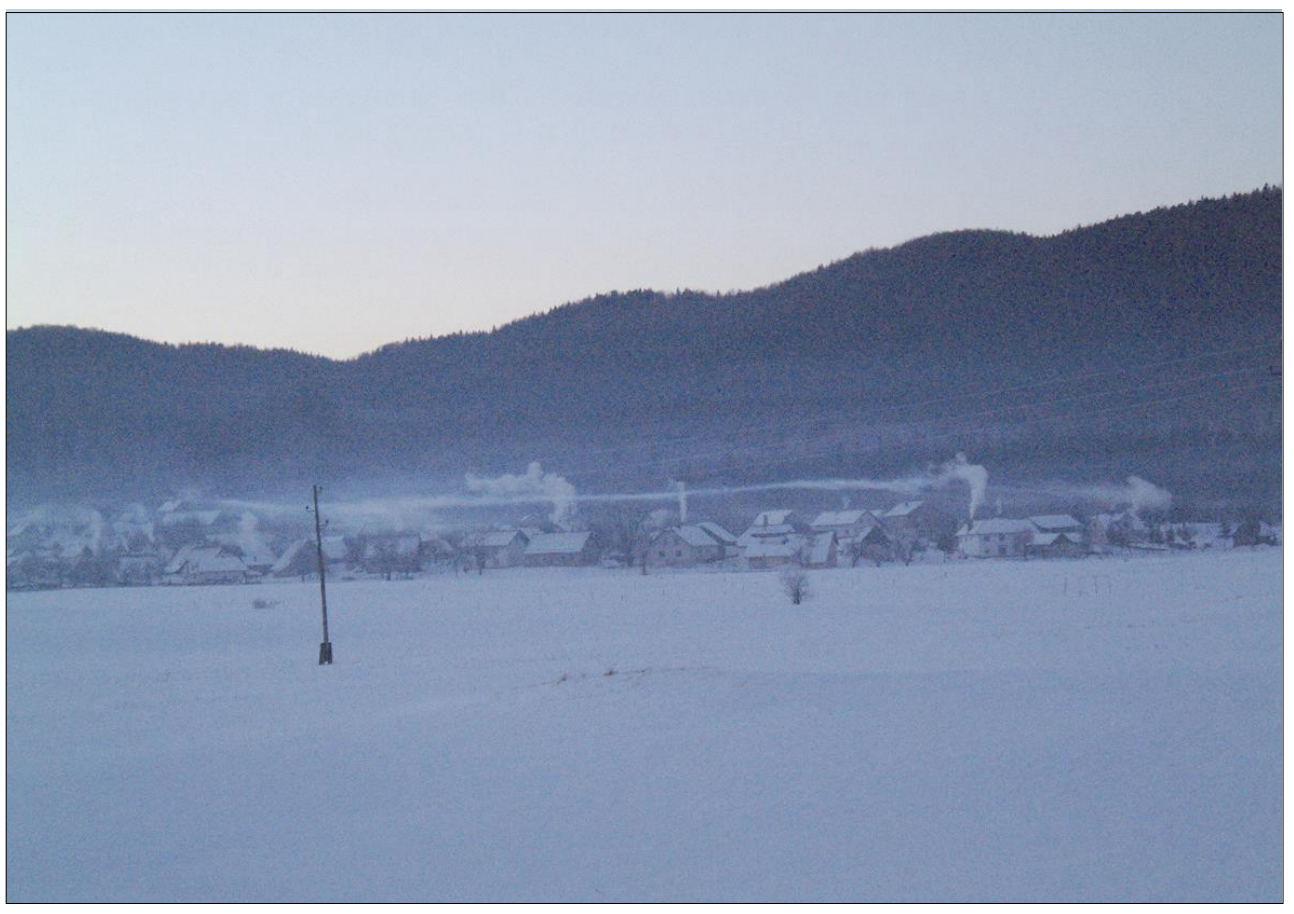

\section{MERITVE MINIMALNIH TEMPERATUR POZIMI 2004/2005}

Na Oddelku za geografijo, Filozofske fakultete v Ljubljani, smo se v letu 2004 odločili, da poskusno izvedemo meritve minimalnih temperatur zraka v območjih, ki jih že poznamo kot mrazišča, oziroma, za katere smo domnevali, da se v njih ob izpolnjenih meteoroloških pogojih pojavijo nižje temperature, kot na merilnih mestih, kjer se merijo temperature $\mathrm{v}$ mreži ARSO. Zimo 2004 / 2005 smo predvideli kot poskusno obdobje, za merjenja zračnih minimumov s Sixovimi termometri. Pokazale naj bi se osnovne razlike med posameznimi mrazišči, ki bi prišle prav v nadaljnjih meritvah.

Najnižja uradno izmerjena temperatura v Sloveniji je $-34,5{ }^{\circ} \mathrm{C}$ iz 15 . in 16. februarja leta 1956 na Babnem Polju. Že dejstvo, da merilno mesto na Babnem Polju leži kakih 10m nad dnom polja govori v prid temu, da morajo biti temperaturni minimumi na Babnem Polju v resnici nižji od dejansko izmerjenih, kajti najnižje temperature se, v skladu z dejstvom, da je hladen zrak težji od toplega, pojavljajo v najnižjih zračnih plasteh. 
Da se v Sloveniji verjetno pojavljajo še nižje temperature kot na Babnem Polju, smo lahko sklepali po podatkih iz drugih alpskih mrazišč v sosednjih državah. V avstrijskem Grünloch so leta 1930 namerili le $-52.6^{\circ} \mathrm{C}$. (Klimatographie von Österrreich, 1960) Temperature pod $-40^{\circ} \mathrm{C}$ pa se pogosto pojavljajo tudi v drugih alpskih mraziščih kot so Grünloch, Glattalp, Funtensee in drugi. (medmrežje 1) Večina teh mrazišč leži na nadmorski višini med 800 in $2000 \mathrm{~m}$, za vse pa velja, da so v konkavnih reliefnih oblikah brez odtoka zraka v najnižji točki.

V dinarsko-kraških pokrajinah Slovenije so konkavne reliefne oblike (udornice, vrtače, drage, kraška polja, podolja) najbolj značilni elementi pokrajine. Veliko takih oblik pa najdemo tudi v Alpskem svetu, saj je z izjemo Pohorja, Travnika in Smrekovca zgrajen pretežno iz karbonatnih kamnin. Seveda se konkavne reliefne oblike pojavljajo tudi v nekarbonatnih pokrajinah, le da jih je tam manj.

Ker se temperaturne razmere nad vzhodnimi Alpami bistveno ne razlikujejo (severni del je pogosto malenkost hladnejši), je bilo izhodišče naše raziskave, da se tudi v mraziščih v Sloveniji pojavljajo temperature, ki so primerljive s tistimi v ostalih alpskih mraziščih.

\section{Metodologija raziskovanja}

V poskusnem letu raziskave smo se odločili za merjenje minimalnih temperatur z alkoholnimi Sixovimi termometri, saj za razliko od živo srebrnih termometrov delujejo tudi pri temperaturah pod $-40^{\circ} \mathrm{C}$. Termometri zabeležijo najnižjo in najvišjo temperaturo v obdobju od zadnjega odčitavanja. Termometre smo postavili na lokacije v različnih slovenskih pokrajinah, za katere smo predvidevali, da so mrazišča. Termometri so imeli radiacijski ščit, narejen iz srebrne aluminizirane folije, s številnimi odprtinami, ki so omogočale prost pretok zraka. Pokriti so bili z majhno strešico, od spodaj pa so bili odprti. Kjer je zaradi večje vetrovnosti obstajala nevarnost, da bi padavine omočile ali zamedle termometer z radiacijskim ščitom vred, smo postavili še zaščito iz sive pločevine. Ker so nas zanimale minimalne temperature, ki se pojavljajo ponoči ob odsotnosti svetlobe (in s tem učinka albeda) ocenjujemo, da smo zadovoljili pogojem objektivnosti in primerljivosti temperature. Termometri so bili postavljeni na višini med 2 in $3 \mathrm{~m}$ nad tlemi, pri čemer je bilo kriteriju stalne višine od tal zaradi spreminjajoče višine snežne odeje težko ustreči.

Izbrali smo naslednje lokacije.

V Alpskih pokrajinah Lepo Komno (n.v. okoli 1600m) in Najen v Tamarju (1020m), v Predalpskih pokrajinah Poljano na Koroškem (440m), v Dinarskokraških pokrajinah Smrekovo Drago $(1060 \mathrm{~m})$ in Malo Lazno $(1100 \mathrm{~m}) \mathrm{v}$ Trnovskem gozdu, Lepi dol pri Leskovi dolini (780m), ter Babno polje $(750 \mathrm{~m})$, v Submediteranskih pokrajinah pa Zalipnik v Čičariji (770m) in Movražko valo (147m).

$\mathrm{Z}$ nastopom prvih nižjih temperatur v drugi polovici decembra 2004 se je pokazalo, da je večina Sixovih termometrov kljub drugačnim zagotovilom proizvajalca, pri temperaturah pod okoli $-20^{\circ} \mathrm{C}$ neuporabnih, saj se je pri večini termometrov alkoholna palčka v termometru prelomila in termometer je prenehal delovati.

Tako je ta metoda meritev dala uporabne rezultate le v mraziščih, kadar se ekstremno nizke temperature niso pojavljale, vseeno pa so bile izmerjene velike razlike glede na okolico. 
Za merjenje temperature v mraziščih smo se po odpovedi Sixovih minimalnih termometrov odločili za metodo maršrutnih meritev z digitalnim termometrom Testo. Prednost te metode v primerjavi s prejšnjo je delovanje termometra pri temperaturah do $-50^{\circ} \mathrm{C}$, slabost pa, da mora biti med meritvami človek ves čas zraven. $Z$ metodo maršrutnih meritev smo lahko minimalno temperaturo določili le približno, in sicer tako, da smo se odpravili meriti tik pred sončnim vzhodom. Ob tem so morali biti izpolnjeni pogoji, da je bilo vreme vso noč mirno in jasno in je lahko temperatura nemoteno padala do jutra. Merilna sonda je opremljena z radiacijskim ščitom, vseeno pa zlasti ob sončnem vremenu in če je sonda izpostavljena neposrednemu sončnemu sevanju, kaže 1 - 3 stopinje previsoke temperature. Ker pred sončnim vzhodom neposrednega sončnega sevanja ni, sevalna bilanca pa se tedaj približa ničli (tik preden jutranja temperatura začne naraščati je neto sevalna bilanca tal in atmosfere enaka nič), je pomanjkljivost sevalnega ščita najmanjša. Pojavi pa se še en učinek, ki prispeva k napaki merjenja, to je toplotno sevanje osebe, ki meri temperaturo. Čeprav se meri s približno $25 \mathrm{~cm}$ dolgo sondo, ki jo oseba drži stran od sebe, je vedno prisoten majhen sevalni pribitek k vrednosti, ki jo izmerimo. Prav tako se ob zelo nizkih temperaturah nad osebo ki meri, dviga topel zrak, ki ga oseba izdiha. Ta zrak obstane v plasti in nekaj časa vpliva na dvig temperature. Če ocenimo vse vplive lahko sklenemo, da so vrednosti izmerjene z maršrutnimi meritvami z digitalno sondo znotraj intervala $\pm 1.5^{\circ} \mathrm{C}$.

\section{Rezultati}

Kot rečeno, so Sixovi termometri pri temperaturah pod $-25{ }^{\circ} \mathrm{C}$ odpovedali, kljub temu pa smo dobili nekaj zanimivih rezultatov $\mathrm{v}$ obdobju ko je prevladovalo radiacijsko vreme $\mathrm{v}$ razmeroma toplem zraku in so $v$ mraziščih vladale povsem druge razmere. $V$ nadaljevanju navajamo nekaj rezultatov in ugotovitev.

\section{Smrekova draga}

Smrekova Draga, 12.12. 2004: temperature na severnem obodu $(1200 \mathrm{~m})$ drage $5^{\circ} \mathrm{C}$, na dnu pa $-7^{\circ} \mathrm{C}$.

Gradient v času merjenja je znašal 12 stopinj na $140 \mathrm{~m}$.

Smrekova Draga je znano mrazišče na Trnovski planoti, kjer je na pobočjih prisoten tudi vegetacijski obrat. Dno je neporaslo z gozdom oziroma ga prerašča redko planinsko rušje (pinus mugo). Gams (Gams 1972) navaja, da neporaslost dna ni samo klimatsko pogojena, pač pa tudi zaradi poseka ali požiga in da so procesi sukcesije zaradi slabih rastnih pogojev zelo počasni. Planinsko rušje na senčni strani Smrekove drage uspeva precej bolj uspešno kot smreka, ki sicer uspešno raste na severnem (sončnem) robu vse do dna Smrekove drage. Ali je na dnu drage v resnici dovolj mrzlo, da gozd ne uspeva, bo pokazal čas. Meritve v zimi 2004 / 2005 so pokazale, da zaradi nizkega severnega in severovzhodnega roba (sega do višine okoli 1200m) ob vetrovih iz severnega kvadranta Smrekovo drago hitro prevetri. Burja, ki je na območju Trnovske planote zelo pogosta in vztraja zelo dolgo ter dosega tudi orkanske hitrosti, prepreči ohlajanje in s tem padec temperature $\mathrm{v}$ mrazišču. Nasprotno se v toplem zraku ob mirnem anticiklonalnem vremenu, ko burje ali drugih vet- 
rov ni, mrazišče izrazito ohladi. Visok južni rob (okoli 1400m) omogoči zadrževanje hladnega zraka v mrazišču, saj ga nizko zimsko sonce ne doseže. Seveda so temperature v toplem zraku višje, temperaturne razlike med obodom in dnom pa vseeno velike.

\section{Najen, Rateče}

Mrazišče Najen v dolini Tamar leži ob cesti v Tamar na višini $1020 \mathrm{~m}$. Spoznamo ga po edinem območju ob cesti, kjer v večjem obsegu raste planinsko rušje (pinus mugo). Mrazišče se je izkazalo za najhladnejše mesto vzdolž ceste od planiških skakalnic do koče v Tamarju, saj smo poleg meritev v Najenu izvedli tudi maršrutne merive z digitalnim termometrom po dolini.

Tabela 1: Temperaturni profil od Rateč do koče v dolini Tamar.

Table 1: Temperature profile from Rateče to Alpine hut in Tamar valley.

\begin{tabular}{|l|l|l|c|}
\hline ura & $\begin{array}{l}\text { nadmorska } \\
\text { višina }\end{array}$ & 21.12. 2004 & temperatura \\
\hline $7: 00$ & $864 \mathrm{~m}$ & Rateče-merilna postaja ARSO. & $-13.1{ }^{\circ} \mathrm{C}$ \\
\hline $7: 40$ & $950 \mathrm{~m}$ & Planica-zapornica ceste v Tamar. & $-14.4^{\circ} \mathrm{C}$ \\
\hline $7: 50$ & $970 \mathrm{~m}$ & Vrh prvega klanca od zapornice. & $-12.9^{\circ} \mathrm{C}$ \\
\hline $8: 00$ & $1010 \mathrm{~m}$ & Vrh drugega klanca, pri klopci. & $-15.3^{\circ} \mathrm{C}$ \\
\hline $8: 05$ & $1005 \mathrm{~m}$ & Zaledenelo občasno jezero. & $-15.0^{\circ} \mathrm{C}$ \\
\hline $8: 10$ & $1058 \mathrm{~m}$ & Vrh tretjega klanca-tabla TNP $($ desno na dnu manjše čistine). & $-17.3^{\circ} \mathrm{C}$ \\
\hline $8: 15$ & $1039 \mathrm{~m}$ & Najen dno. & $-19.9^{\circ} \mathrm{C}$ \\
\hline $8: 20$ & $1058 \mathrm{~m}$ & Vrh klanca nad Najenom. & $-17.5^{\circ} \mathrm{C}$ \\
\hline $8: 35$ & $1103 \mathrm{~m}$ & Tamar-začetek travnika pri planinski koč pri tabli TNP. & $-13.5^{\circ} \mathrm{C}$ \\
\hline $9: 10$ & $950 \mathrm{~m}$ & Ponovno zapornica v Planici. & $-13.5^{\circ} \mathrm{C}$ \\
\hline $8: 00$ & $864 \mathrm{~m}$ & Rateče-merilna postaja ARSO. & $-13.5^{\circ} \mathrm{C}$ \\
\hline
\end{tabular}

Dolina Tamar se vzpenja neenakomerno. Cesta, vzdolž katere smo opravljali meritve, vodi po vzhodnem delu in se vzpenja v več klancih, katerim sledijo manjši spusti. To so nekakšne stopnje, $v$ katerih se hladen zrak nabira in ne more odteči nemoteno proti Ratečam. Občasno se v njih nabira tudi voda. V smeri proti Ratečam je bil ob vseh merjenjih opazen izrazit dolnik, ki ga je bilo zaznati zlasti na vrhu stopenj, na pa na njihovih najnižjih delih. Razgibanost reliefa na dnu doline omogoča nabiranje hladnega zraka, nad katerim pa ves čas mrzel zrak odteka proti Ratečam. Dokaz o prisotnosti dolnika v večernem, nočnem in jutranjem času je lepo viden, kadar pozimi pri skakalnicah obratujejo snežni topovi. Tedaj sneg odnaša v smeri proti Ratečam.

Ugotovili pa smo, da se na dnu doline pri Ratečah, nad zaledenelim jezerom Ledine nahaja še eno pomembno jezero hladnega zraka, ki je ob nekaterih merjenjih dalo celo nižje temperature kot Najen.

Tako smo 30.1. 2005 med $7^{00}$ in $8^{00}$ uro namerili:

- Rateče - jezero Ledine: $-28.4{ }^{\circ} \mathrm{C}$,

- Najen: $-24.3{ }^{\circ} \mathrm{C}$. 
Dolnik ki teče proti Ratečam tega jezera ne premeša, saj bi sicer bile temperature v njem višje. Pogoji za dolnik so namreč izpolnjeni le toliko časa, dokler so višje ležeči predeli hladnejši (in zato težji) od nižje ležečih. Mogoče je, da teče dolnik proti Ratečam nekoliko višje nad tlemi ali pa se že preje obrne v smeri proti Kranjski Gori, kamor se spušča Zgornjesavska dolina. To bi pojasnile meritve vetra nekaj $10 \mathrm{~m}$ nad tlemi.

Slika 2: Pogled v mrazišče Najen. Ko je dan najkrajši, ostane na dnu ivje ves dan na rastju. Lepo je vidno zmanjševanje ivja in snega na drevju z višino, kar je dokaz močne talne inverzije. (Fotografija: Matej Ogrin)

Picture 2: A view to Najen. When winter day light is short, rime stays on a vegetation all day. The decreasing of rime and snow on vegetation with height shows us the height of strong temperature inversion. (Photo: Matej Ogrin)

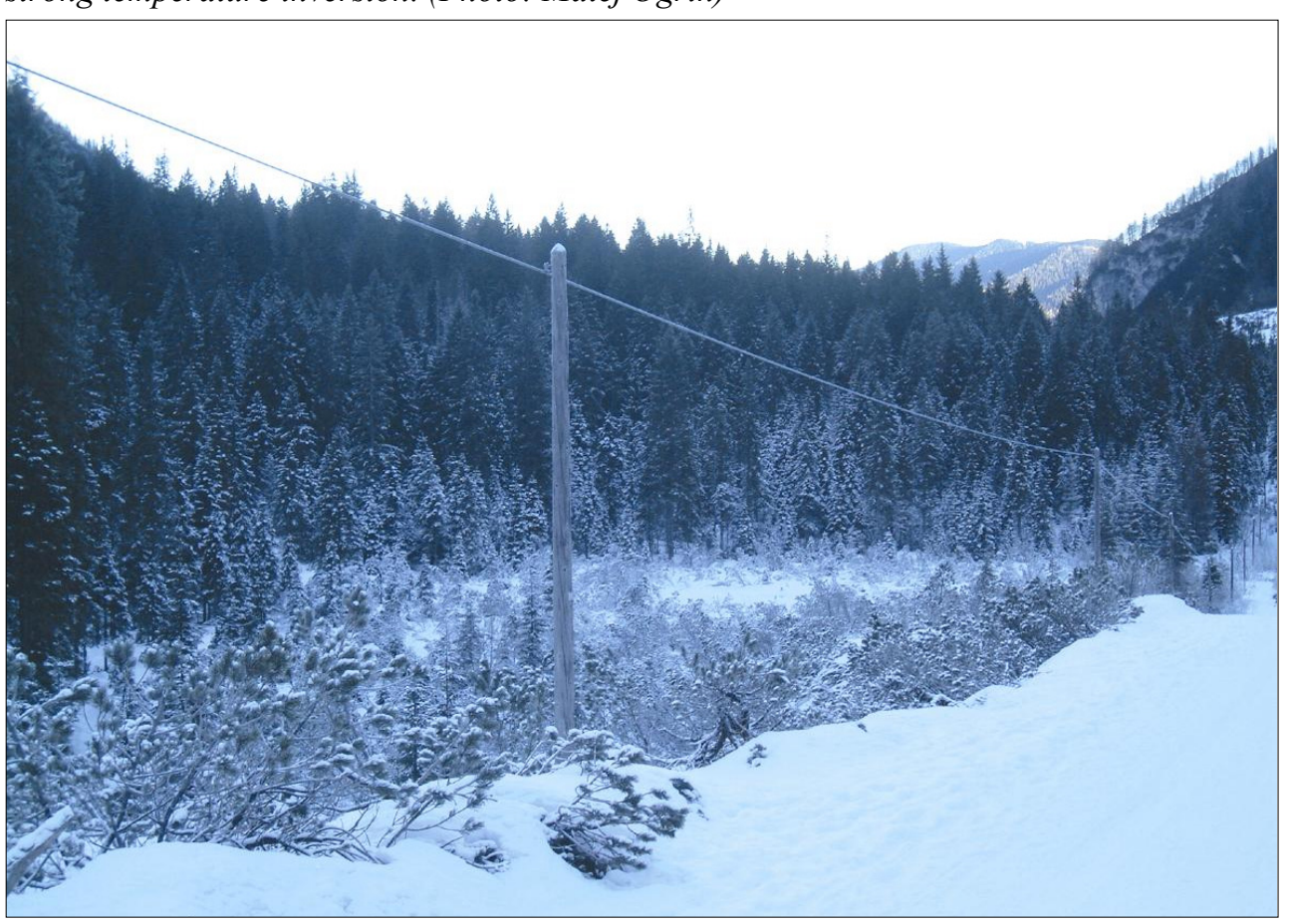

Temperature niso bile izmerjene ob isti uri, vse pa so v intervalu ene ure. V jasnih nočeh se temperature $v$ drugem delu noči in $v$ jutranjih urah pred sončnim vzhodom precej manj spreminjajo kot pa zvečer in v prvem delu noči, kar jasno kaže tabela 2. Tabela 1 vsebuje tudi podatke izmerjene na postaji ARSO v Ratečah (Arhiv ARSO), kjer je očitno, da je razlika med temperaturama izmerjenima ob 7 . uri in ob 8 . uri zjutraj le 0.4 stopinje. Zato temperaturne razlike, ki smo jih namerili med meritvijo v Tamarju, kažejo razlike v temperaturah po kraju in ne po času (oziroma je ta člen zanemarljiv). 
Tabela 2.: Intenzivnost ohlajanja ob radiacijskem tipu vremena v noči z 21.- 22. decembra 2005 v Ratečah. (vir: Arhiv ARSO).

Table 2.: Intensity of nocturnal cooling at radiative type of weather in Rateče from 21. to 22. December (source: acrhives of ARSO).

\begin{tabular}{|c|c|c|}
\hline ura & temperatura & \multirow{9}{*}{$\Delta \mathrm{T} / \Delta \mathrm{t}\left(16^{00}-24^{00}\right)=-0.8^{\circ} / \mathrm{h}$} \\
\hline $16^{00}$ & -4.3 & \\
\hline $17^{00}$ & -5.5 & \\
\hline $18^{00}$ & -7.0 & \\
\hline $19^{00}$ & -6.9 & \\
\hline $20^{00}$ & -9.6 & \\
\hline $21^{00}$ & -10.1 & \\
\hline $22^{00}$ & -10.6 & \\
\hline $23^{00}$ & -11.1 & \\
\hline $24^{00}$ & -11.6 & \multirow{9}{*}{$\Delta \mathrm{T} / \Delta \mathrm{t}\left(24^{00}-08^{00}\right)=-0.2^{\circ} / \mathrm{h}$} \\
\hline $01^{00}$ & -11.5 & \\
\hline $02^{00}$ & -11.6 & \\
\hline $03^{00}$ & -12.4 & \\
\hline $04^{00}$ & -12.7 & \\
\hline $05^{00}$ & -12.7 & \\
\hline $06^{00}$ & -13.2 & \\
\hline $07^{00}$ & -13.1 & \\
\hline $08^{00}$ & -13.5 & \\
\hline
\end{tabular}

\section{Lepa Komna}

Najbolj so nas zanimale razmere v sredogorskih alpskih mraziščih, saj smo tam predvidevali najnižje temperature. Na Lepi Komni smo pod Srednjim vrhom (1590m) postavili Sixov termometer, ki pa je že v decembru odpovedal. Že kmalu smo ugotovili, da so ob jasnih dneh v številnih majhnih kotanjah, ki so na dnu mrazišč, temperature tik nad tlemi, vse dokler je udorina v senci, precej nižje kot zunaj njih. Še večje razlike pa se pojavijo, ko mrazišče ali njegov del obsije sonce, dno majhnih kotanj pa je še vedno v senci.

Dne 17.1.2005 je na eni od teh kotanj, na višini 1.8 metra ob 10:50 znašala temperatura $-16^{\circ} \mathrm{C}$, istočasno pa je znašala temperatura na $5 \mathrm{~cm}$ nad tlemi $-23^{\circ} \mathrm{C}$.

Preostanek zime smo merili temperature z maršrutnimi meritvami. Ob spremljanju meteo-roloških razmer smo opravili meritve $v$ dneh, ko so se $v$ mraziščih pojavili ugodni pogoji za nastanek nizkih temperatur.

Take razmere so bile med 6 . in 10. februarjem 2005. 8. februarja smo v mrazišču pod Srednjim vrhom namerili $-29.5^{\circ} \mathrm{C}$, odkrili pa smo dve novi mrazišči, vzhodneje od prvega, kjer smo isto jutro namerili -33.0 oziroma $-34.2{ }^{\circ} \mathrm{C}$.

To jutro so ob 7. uri na Babnem Polju namerili $-26.8{ }^{\circ} \mathrm{C}$, pri čemer je potrebno poudariti, da tam temperature niso merjene na dnu polja. Pokazalo se je, da so temperature $\mathrm{v}$ mraziščih na Lepi Komni vsaj primerljive s tistimi na Babnem Polju. 
Za zelo nizke temperature so nastopili izjemno ugodni pogoji od 28. februarja do 3. marca, ko je polarni zrak preplavil območje Alp. V tistih dneh so marsikje po osrednji Sloveniji padli marčevski rekordi in najnižje temperature v zimi 2004/2005.

Slika 3: Temperature na dnu kotanj tudi več ur po sončnem vzhodu vztrajajo pod $-20^{\circ} \mathrm{C}$. (Fotografija: Matej Ogrin)

Slika 3: Temperatures at the bottom of shallow hollows even more hours after sunrise remains under $-20^{\circ} \mathrm{C}$. (Photo: Matej Ogrin)

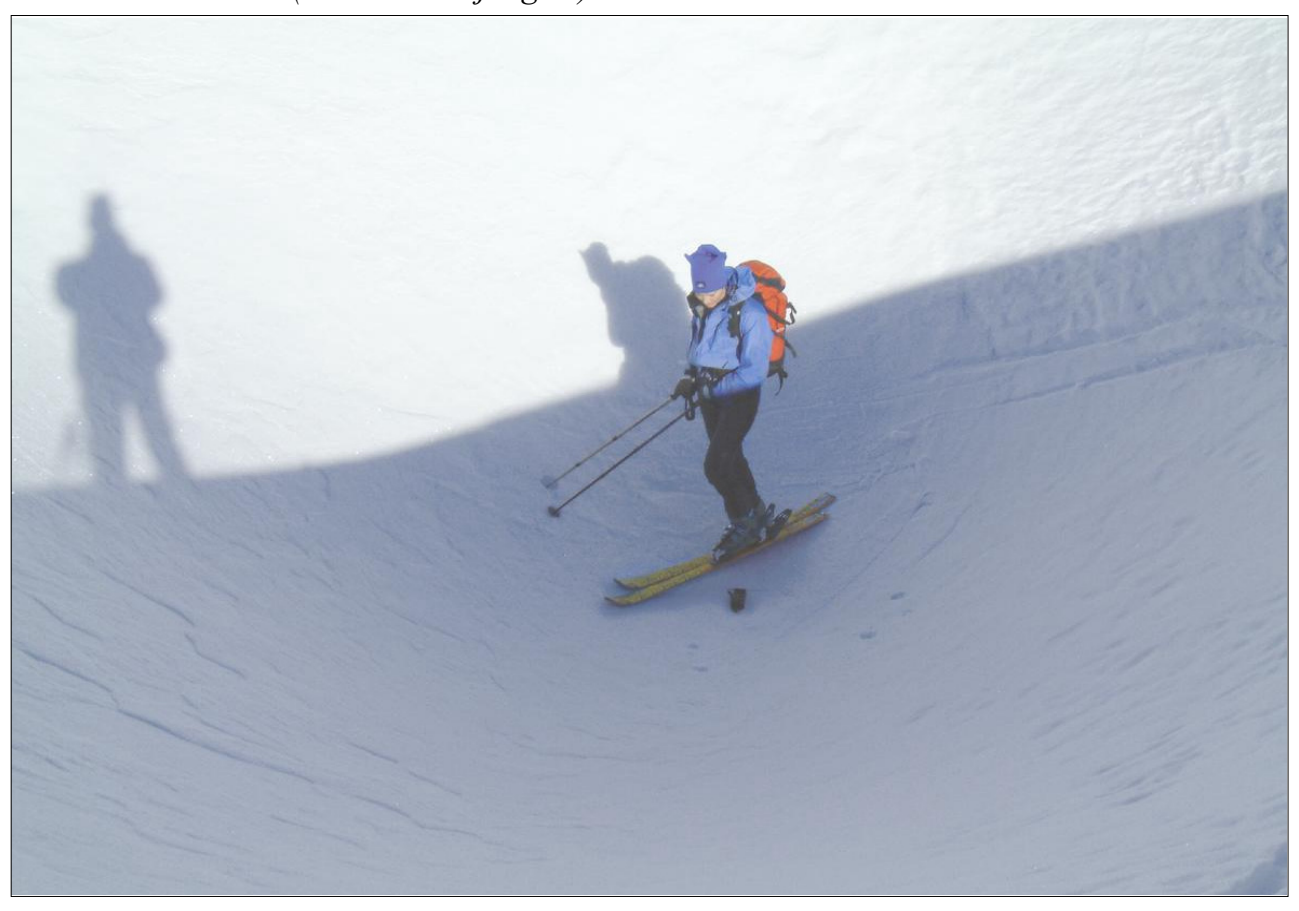

2. marca smo v mrazišču na Lepi Komni namerili $-41.1^{\circ} \mathrm{C}$. Kljub dejstvu, da ne gre za uradno izmerjeno vrednost, nas te vrednosti opozarjajo na razmere, ki vladajo $\mathrm{v}$ sredogorskih mraziščih in kažejo na upravičenost domnev, da v višje ležečih mraziščih temperature padejo precej nižje od uradno izmerjenih minimumov.

Kot primerjavo navajamo temperature, ki so jih v jutrih od 1. do 3. marca 2005 on 7 uri namerili na Babnem Polju. Ta postaja je izmerila najhladnejše temperature v mreži ARSO.

Tabela 3: Temperature na Babnem Polju ob 7. uri od 1. do 3. marca 2005.

Table 3: Temperatures on Babno Polje at 7 AM. from 1. to 3. March 2005.

\begin{tabular}{|l|l|l|l|}
\hline datum & 1. marec & 2. marec & 3. marec \\
\hline temperatura & $-30.0{ }^{\circ} \mathrm{C}$ & $-29.4{ }^{\circ} \mathrm{C}$ & $-28.0{ }^{\circ} \mathrm{C}$ \\
\hline
\end{tabular}

Vir: arhiv ARSO 
Karta 1 : Prostorska razporeditev minimalnih temperatur na prehodu kraškega v flišni del Slovenske Istre 27.12.2003.

Map 1 : Spatial distribution of minimum temperatures at boundary from carst to flysch Istria on 27. December 2003.

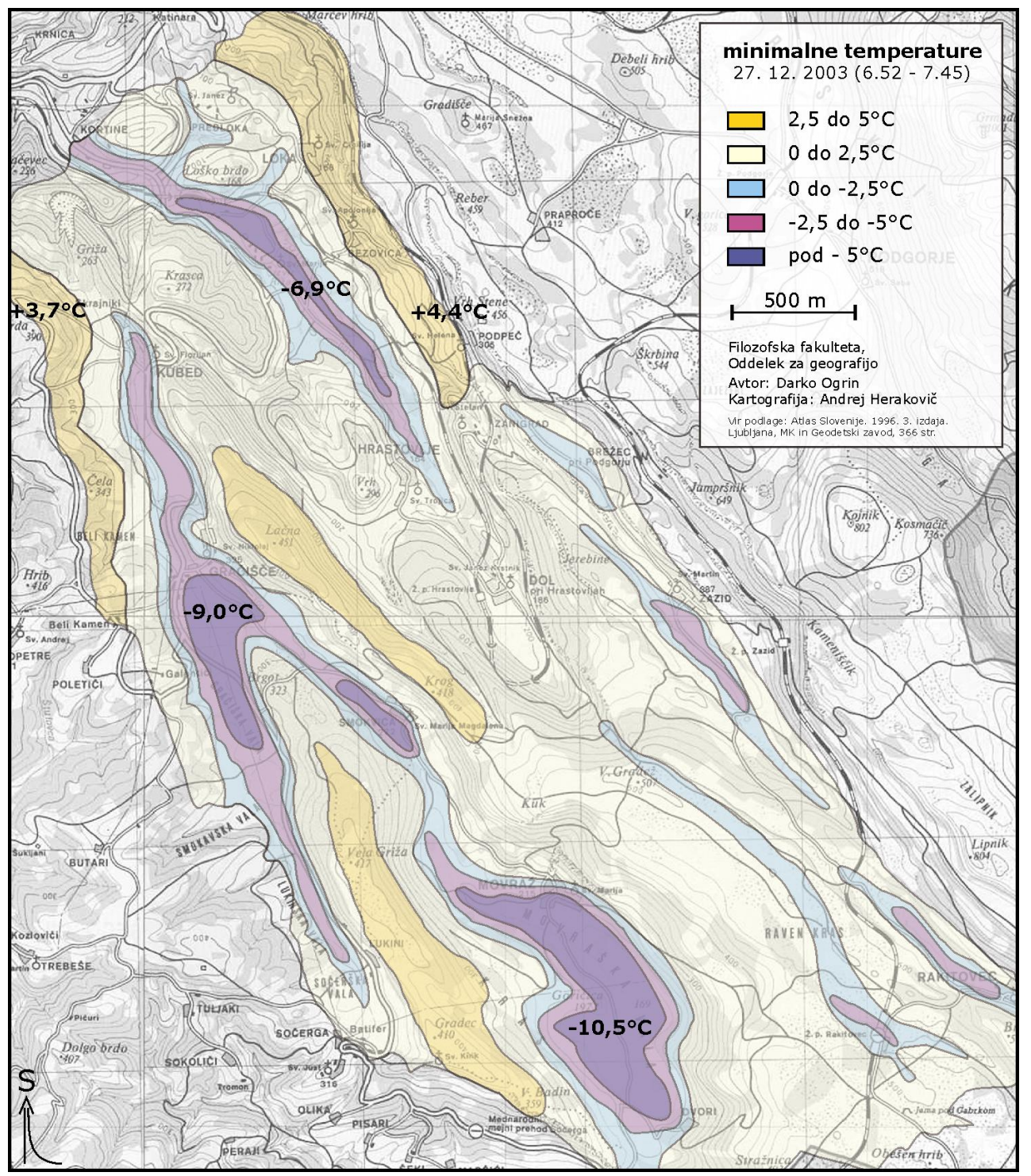

\section{Zalipnik in Movraška vala}

Dosedanje meritve minimalnih temperatur v Slovenski Istri (npr. Ogrin D., 1994) so pokazale, da so ugodni pogoji za pojav minimalnih temperatur tudi v tej pokrajini. Kot lokalna 
pola mraza sta se kljub nizki nadmorski višini izkazali Gračiška (n.v. $280 \mathrm{~m}$ ) in še posebno Movraška vala (n.v. 170 m), ki sta nastali na prehodu kraškega v flišni del Slovenske Istre in imata obliki plitvih, večinoma zatravljenih kotanj. Maršrutne meritve 27.12.2003 nekaj pred sončnim vzhodom so npr. pokazale, da se je dno Gračiške vale ohladilo na $-9,1{ }^{0} \mathrm{C}$, dno Movraške vale pa na $-10,5{ }^{\circ} \mathrm{C}$, medtem ko so bile temperature na 50 do $70 \mathrm{~m}$ višjem obodu val 10 do $12{ }^{\circ} \mathrm{C}$ višje.

Pozimi 2004/2005 smo Sixov termometer postavili v Movraško valo in za primerjavo tudi v plitvo travnato podolje z nizom vrtač Zalipnik (n.v. $785 \mathrm{~m}$ ) med grebenom Lipnika in Goliča v slovenskem delu Čičarije. V prvem obdobju meritev med 28.11. in 29.12. 2004, ko tudi na najvišjih delih Čičarije ni bilo snega, se je v Movraški vali ohladilo do $-15,0{ }^{\circ} \mathrm{C}$, v Zalipniku, kljub precej višji nadmorski višini, pa le do $-12,5{ }^{\circ} \mathrm{C}$. Rezultat si razlagamo z večjo prevetrenostjo Zalipnika in slabšimi pogoji za zadrževanje hladnega zraka, saj podolje rahlo visi proti SZ. V zadnji tretjini zime 2004/2005, ko je v notranjosti Slovenske Istre zapadel sneg, smo med 5.2. in 6.3. 2005 v Movraški vali namerili $-16,5{ }^{\circ} \mathrm{C}$, v Zalipniku pa je termometer odpovedal, po čemer sklepamo, da se je temperatura spustila pod $-20{ }^{\circ} \mathrm{C}$.

\section{SKLEP}

Prvi izsledki raziskave kažejo, da se temperature v mraziščih spustijo nižje, kot je moč sklepati iz podatkov dobljenih v mreži ARSO. Sredogorska mrazišča se lahko bolj ohladijo kot nižje ležeča mrazišča kraških polj, zaradi večje vetrovnosti pa je povsem mogoče, da se to ne dogaja tako pogosto. Podatki, izmerjeni na Lepi Komni tudi kažejo, da so temperaturne razmere $\mathrm{v}$ naših mraziščih primerljive $\mathrm{s}$ tistimi drugje $\mathrm{v}$ Alpah ( $\mathrm{v}$ Bavarskem mrazišču Funtensee so v obdobju 29. 2. -3.3 .2005 namerili $-43.6{ }^{\circ} \mathrm{C}$, kar je najnižja izmerjena temperatura v Alpah v zimi 2004 /2005). Podatke o tem, kje vse se v Sloveniji pojavljajo ekstremna mrazišča in kje so najhladnejša med njimi, pa nam bo dalo raziskovanje v prihodnjih letih.

\section{Viri in literatura}

ARHIV ARSO. Temperaturni podatki meteoroloških postaj Rateče in Babno Polje.

Barany I, 1967. Der Einfluss des Niveauunterschiede und der Exposition auf die Lufttemperatur in einer Doline im Bück-Gebirge. Acta climatologica, Acta universitatis szegediensis, t. VII, f: 1-4, Szeged.

Gams I, 1972. Prispevek k mikroklimatologiji vrtač in kraških polj. Geografski zbornik, XIII, SAZU, Ljubljana, 77 str.

Gams I, 1974, K ekologiji vrtač. V: Zbornik IX kongresa geografa Jugoslavije u Bosni in Hercegovini od 24. do 30. IX. 1972, Sarajevo: Geografsko društvo Bosne i Hercegovine, 1974. Str. 151-159.

Gams I., Lovrenčak F., Ingolič B., 1979. Krajna vas-študija prirodnih pogojev in agrarnega izkoriščanja krasa. Geografski zbornik X, Inštituta za geografijo SAZU Ljubljana. 
Klimatographie von Österrreich, 1960, Österreic. Akad. Wiss. Wien cit. po Gams I, 1972. Medmrežje 1: http://forum.weather-photos.net/index.php, citirano 6.5. 2005.

Ogrin D., 1995. Podnebje Slovenske Istre, Knjižnica Annales 11, Koper.

Petkovšek Z. , Gams I., Hočevar A., 1969. Meteorološke razmere v profilu Drage. Zbornik Biotehnične fakultete.

Wagner R., 1970. Kaltluftseen in den Dolinen. Acta climatologica, T. IX, f. 1-4. Szeged.

\title{
PRELIMINARY REPORT ABOUT MEASURING EXTREME NOCTURNAL TEMPERATURES IN CONCAVE RELIEF SHAPES IN WINTER 2004/2005
}

\begin{abstract}
Summary
Concave relief shapes are known as areas with extreme nocturnal cooling in radiative type of weather. The shape of valleys, basins, uvalas, karst fields etc. is very important for forming of cold air pool, which influences on air temperatures.

Conditions when extreme nocturnal cooling appears are connected with calm and clear sky, cold air, dry atmosphere and fresh snow cover.

In Alpine areas, shallow valleys and hollows are known as places with extreme minimum temperatures. Some researches were made also in Slovenia although they were mainly concentrated on dinaridic region, where concave relief shapes are common, and where the coldest temperatures in Slovenia were measured. However, the theoretical basis and measurements made in other Alpine countries lead us to predictions, that also Slovenian Alpine area sometimes conditions for extreme nocturnal cooling in concave relief shapes are fulfilled. Measurements on Komna plateau and Tamar-Rateče valley confirmed these predictions, however, also dinaridic regions with karst fields and uvalas were recognized as region with very low nocturnal temperatures in radiative type of weather. The temperatures, measured on Komna plateau in winter 2004/2005 were even lower, than the minimum temperatures officially measured in Slovenia until now. The data also confirmed the prediction, that minimum temperatures in Slovenian Alpine area don't differ much from temperatures in other Alpine countries. Due to various mountainous karst relief, further measurements must be done in coming years, to get the data of coldest spots in Slovenia.
\end{abstract}

